\title{
Bryostatin 1
}

National Cancer Institute

\section{Source}

National Cancer Institute. Bryostatin 1. NCI Thesaurus. Code C1026.

A macrocyclic lactone isolated from the bryozoan Bugula neritina with antineoplastic activity. Bryostatin 1 binds to and inhibits the cell-signaling enzyme protein kinase $C_{\text {, }}$ resulting in the inhibition of tumor cell proliferation, the promotion of tumor cell differentiation, and the induction of tumor cell apoptosis. This agent may act synerg istically with other chemotherapeutic agents. (NCl04) 